\title{
TEORI MAQASHID AL-SYARI'AH DAN PENERAPANNYA PADA PERBANKAN SYARIAH
}

\author{
M. Ziqhri Anhar Nst \\ UIN Sumatera Utara \\ anharnst88@gmail.com \\ Nurhayati \\ UIN Sumatera Utara \\ nurhayati@uinsu.ac.id
}

\begin{abstract}
Abstrak Maqashid Al-Syari'ah bertujuan untuk mencapai kemaslahatan dan mencegah kemudharatan dalam kegiatan ekonomi Maqashid AlSyari'ah berguna dalam pembangunan ekonomi yang membahas tentang masalah ekonomi, fenomena ekonomi, dan merumuskan suatu kebijakan. Ulama-ulama klasik maupun kontemporer banyak yang memberikan pendapat mengenai maqashid al-syariah, namun al-syatibi merupakan teori yang paling terkenal. Teori Maqashid Al-Syari'ah sendiri bermakna sebagai inti dalam menganalisis ekonomi yang membahas tentang kemiskinan, distribusi kekayaan, dan membangun ekonomi. Dalam hal ini yang ingin dicapai Maqashid Al-Syari'ah adalah penghilangan segala permasalahan ekonomi untuk mencapai kehidupan yang sejahtera Dalam penerapannya pada sistem keuangan islam Maqashid Al-Syari'ah sebagai inti dalam keberlangsungan kegiatan ekonomi karena tanpa Maqashid Al-Syari'ah keuangan islam kehilangan substansi syariahnya. Tujuan penelitian ini adalah melihat dan mengetahui bagaimana teori maqashid al-syari'ah dan penerapannya pada perbankan syariah. Metode yang digunakan adalah penelitian perpustakaan (library research) ,Peneliti mencari sumbersumber yang berasal dari buku,jurnal dan artikel yang berkaitan dengan maqashid al syariah yang selanjutnya setelah diproleh peneliti mengolah data dengan mengaitkannya pada fenomena yang ada di perbankan syariah pada umumnya. Hasil Penelitian menunjukan bahwa pererapan Maqashid al-syari'ah pada perbankan syariah sudah sesuai dengan memerhatikan indikator pada maqashid al-syari'ah yaitu agama (al-din), jiwa (al-nafs), akal (al-'aql), harta (al-mal), dan keturunan (al-nasl). Begitu juga pada Investasi dengan Akad Mudharabah, pada Jaminan dalam Akad Mudharabah dan Musyarakah, Pada Transaksi Multi Akad, Pada Rahn dan Pemanfaatan Marhun (Barang Gadai), Pada Jual Beli Emas Secara Tidak Tunai.
\end{abstract}

Kata Kunci Maqashid al-syariah, ekonomi islam, lembaga keuangan syariah 


\section{PENDAHULUAN}

Maqashid Al-Syari'ah bertujuan untuk mencapai kemaslahatan dan mencegah kemudharatan dalam kegiatan ekonomi Maqashid Al-Syari'ah berguna dalam pembangunan ekonomi yang membahas tentang masalah ekonomi, fenomena ekonomi, dan merumuskan suatu kebijakan. Pendapat tentang teori Maqashid Al-Syari'ah sudah banyak diutarakan dari zaman Rasulullah SAW konsep Maqashid Al-Syari'ah sendiri telah diutarakan Rasul dan kini terus berkembang dari ulama klasik maupun kontemporer. Maqashid Al-Syari'ah merupakan hal yang penting dalam sistem ekonomi islam Ada berbagai alasan untuk menyebutkan bahwa maqashid adalah inti dari semua analisis ekonomi, terutama yang berkaitan dengan masalah kemiskinan, distribusi kekayaan, dan pembangunan ekonomi Oleh karena itu, target dalam sistem ekonomi islam adalah penghilangan segala bentuk permasalahan ekonomi seperti kemiskinan, pengangguran, ketidakmerataan pembangunan, dan lain-lain dan di sisi yang lain menyediakan segala insentif yang memadai dan dapat diakses oleh semua anggota masyarakat sehingga dapat menikmati segala sumber daya yang tersedia dan mencapai kehidupan yang sejahtera.asyatibi sebagai bapak Maqashid Al-Syari'ah menguraikan tentang prinsip Maqashid Al-Syari'ah yang kini penerapannya banyak digunakan dalam ekonomi \& keuangan Islam. Maqashid Al-Syari'ah sendiri tidak bersifat kaku dan terbatas waktu seiring perkembangan zaman Maqashid Al-Syari'ah dapat menjadi pedoman dalam kegiatan ekonomi islam baik di perbankan syariah, asuransi syariah,koperasi syariah, dan lain-lain.dalam penelitian ini rumusan masalah penulis adalah bagaimana teori dan penerapan maqashid al-syari'ah pada perbankan syariah ,sehingga hasil penelitian ini peneliti dapat memproleh hasil penerapan maqashid al-syari'ah pada perbankan syariah yang berguna untuk akademisi,praktisi, maupun masyarakat umum.

\section{LANDASAN TEORI}

\section{Pengertian Maqashid Al-Syari'ah}

Sesuai ilmu bahasa etimologi, campuran kedua kata dari maqashid al-syariah yaitu maqashid yang memiliki berbagai jenis bentuk diantaranya qashd, maqshad, dan qushud yang menjadi turunan kata kerja dari qashada yaqshudu dan memiliki berbagai arti antara lain mengarah ke sesuatu, sasaran, benar, adil serta terbatas, searah, tidak berlebihan dan kekurangan (Mawardi, 2010). Sesuai bahasa, definisi kaidah maqashid ialah arti kata alqawa'id al-maqashidiyah yaitu kombinasi kedua kata al-qawa'id dan al-maqashidiyah yaitu membahas suatu kaidah yang menghasilkan permasalahan sasaran hukum keislaman dengan sifat umum. Berdasarkan bahasan lain, penulis telah menjelaskan bahwasanya kata al-qawa'id berbentuk jama' ataupun bermacam-macam melalui kata alqa'idah sesuai definisi bahasa yang artinya dasar, prinsip ataupun pedoman umum (Duski, 2019).

Definisi Maqashid Al-Syariah ialah ketetapan dari makna dan tujuan terhadap hukumhukum Allah. Sedangkan berdasarkan istilahnya bahwa Maqashid Al-Syari'ah dari pernyataan Wahbah menerangkan sebagai sekumpulan arti ataupun tujuan yang ingin didapatkan bagi syara' dari seluruh ataupun beberapa permasalahan hukum, dan juga sebagai sasaran syari'at, dan juga dirahasiakan atas perencanaan masing-masing hukum syar'i yang memegang penuh kuasa syari'at, Rasul dan Allah SWT. Maqashid AlSyari'ah juga memiliki arti yang diutarakan para ulama klasik maupun kontemporer (Azharsyah, 2021). Berikut ini beberapa pendapat ulama kontemporer mengenai Maqashid Al-Syari'ah: 
Pendapat dari Imam Al-Syaribi menjelaskan bahwa terdapat dua hubungan Maqashid AlSyari'ah yaitu dengan tujuan Allah sebagai pencipta syariah dan dengan tujuan mukalaf. Tujuan Syari' ialah faedah dan kegunaan bagi setiap hamba berdasarkan dua posisi yaitu dunia serta akhirat. Sedangkan tujuan mukalaf ialah pada saat setiap hamba disarankan untuk melakukan seluruh aktivitas sesuai kegunaan dan faedah di dunia serta akhirat antara lain menyisihkan terjadinya kerusakan di dunia. Oleh sebab itu, diharuskan untuk menghasilkan penafsiran mashlahah (kegunaan) dan mafsadah (kerusakan).

Penjelasan diatas dapat diartikan bahwa Maqashid Al-Syari'ah adalah tujuan yang ditetapkan Allah SWt pada intinya memiliki tujuan untuk mencapai kemaslahatan bagi umat manusia,kemaslahatan bisa tercapai jika pemenuhan kebutuhan priemer (dauriyah),skunder (hajiyat), dan tersier (tahsiniyah) tercapai.

\section{Pembagian Maqashid Al-Syari'ah}

Berdasarkan Al-Syatibi menjelaskan seluruh ketetapan hukum terdiri dari lima bagian utama yang dikenal dengan al-dhuriyat al-khamaah dalam rangka membentuk hukum yang ditekankan dapat dipertahankan. Menjaga agama atau hifzh al-din, menjaga kejiwaan atau hifzh al-nafs, menjaga akal atau hifzh al-'aql, menjaga turunan atau hifzh al-nasl, serta menjaga harta atau hifzh al-nasl adalah semua contoh dari hifzh al-mal. Berbagai ulama memiliki perbedaan perspektif mengenai rentetan al-dharuriyah alkhams, dengan beberapa menempatkan hifzh al-nafs pertama, diikuti oleh hifzh al-din. Selain lima aspek dharuri, beberapa ulama fiqh memasukkan hifzh al-'ird (perlindungan kehormatan). Kemudian ada dua syarat lagi, yang disebut hajiyat dan tahsiniyat. Tingkat pertama adalah daruriyat, diikuti oleh hajiyat, dan terakhir tahsiniyat (Nurhayati \& Imran, 2019)

\section{Maslahah Dauriyat}

Dauriyat adalah kata yang berarti "mendesak, mendasar, dan harus dipenuhi kebutuhan" - Asy-Syatibi berpendapat tentang hal yang termasuk kategori dauriyat yang untuk memperoleh kepentingan penjagaan antara lain : agama (al-din), jiwa (al-nafs), akal (al'aql), harta (al-mal), dan keturunan (al-nasl).

A. Memelihara Agama

Agama keperluan penting dan utama bagi manusia, maka penting dalam menjaga kelestarian dan kemaslahatannya. Cara memelihara agama adalah dengan menunaikan syariat sesuai akidah, beribdah yang tulus, dan berperilaku mulia hal ini harus dilaksanakan agar mencapai kemaslahatan kehidupan.

B. Memelihara Jiwa Jiwa juga dijadikan sebagai keperluan utama yang harus dijaga, maka seluruh sesuatu yang dinilai menjadi wadah memelihara kejiwaan maka bersifat wajib, seperti kebutuhan pangan dalam memelihara tubuh, tidak melakukan pembunuhan antar manusia, dan lainnya. Kewajiban ini bertujuan dalam memelihara eksistensinya seorang manusia serta mewujudkan keamanan dan ketentraman hidup.

C. Memelihara Akal

Akal adalah anugerah Allah dengan memiliki akal manusia bisa menjalankan kehidupan sebagai khalifah di muka bumi.oleh karena itu penting menjaga dan memelihara akal untuk meraih kemaslahatan. tidak mengkonsumsi miras dan narkoba adalah Cara yang dapat dilakukan untuk memelihara akal .

D. Memelihara Harta 
Harta adalah hal yang dibutuhkan dalam keperluan hidup manusia. Dalam islam diajarkan cara yang baik dan benar untuk pencarian dan pengelolaan harta. Oleh karena itu dalam upaya pencarian harta dilarang melakukan tindakan-tindakan menyimpang diantaranya mencuri, korupsi, boros, dan hal hal yang mengandung unsur tidak sesuai syariah.

E. Memelihara Keturunan

Memelihara keturunan salah satu dari keperluan primer manusia. Keturunan adalah generasi yang disiapkan untuk memimpin di muka bumi selanjutnya. Di dalam Islam masalah pernikahan diatur dengan berbagai syarat dan Islam melarang perzinaan yang bisa menodai kemuliaan manusia.

\section{Maslaha Hajiyat}

Hajiyat diartikan sebagai kebutuhan. Jika kebutuhan hajiyat terpenuhi maka mampu mencegah terjadinya kesulitan dalam mencapai keperluan dauriyat, tetapi apabila keperluan hajiyat tidak dipenuhi maka tidak merusak keberadaan kebutuhan dauriyat. Haujiyat sama artinya dengan kebutuhan sekunder. Sebagaimana contoh jika mendirikan sekolah merupakan upaya kebutuhan dauriyat tetapi tidak adanya pembangunan sekolah, pendidikan tidak akan terhentikan, namun memiliki bangunan sekolah dapat mendorong pertumbuhan pemenuhan kebutuhan dauriyat.

3. Maslahah Tahsiniyat

Tahsiniyat memiliki arti hal-hal penyempurna. Dalam hal ini Tahsiniyat merupakan penyempurnaan kebutuhan dauriyat dan hajiyat. Maka dari itu keperluan ini sering diartikan kebutuhan tersier. Sebagaimana contohnya yaitu mempercantik masjid hal ini diperbolehkan selama tidak ada keberatan dalam operasionalnya . meski memiliki sifat tersier aspek faedah tetap sebagai perbandingan pokok yang utama tidak berlawanan dengan nas Ketiga maslahah diatas memiliki keterkaitan satu sama lain (Shodiqqin, 2012)

\section{METODOLOGI PENELITIAN}

Penelitian ini merupakan penelitian perpustakaan (library research) ,Peneliti mencari sumber-sumber yang berasal dari buku,jurnal dan artikel yang berkaitan dengan maqashid al syariah yang selanjutnya setelah diproleh peneliti mengolah data dengan mengaitkannya pada fenomena yang ada di perbankan syariah pada umumnya. Sehingga di peroleh hasil mengenai penerapan maqashid al syariah pada perbankan syariah maupun akad-akad perbankan syariah.

\section{HASIL PENELITIAN}

Pengetahuan (pemahaman) tentang teori-teori syariah pada maqashid al-syariah, landasan filosofis, alasan rasional, mewujudkan illat, rahasia tasyri', dan berbagai metode perumusan diktum-diktum syariah lainnya. Seperti teori qiyas; qiyas jaliy, qiyas khafiy, illat, masalikul'illat, istihsan, maslahah mursalah, sadd al-zariah, 'urf, istishab, takhrijul manath, tanqihul manath, tahqiqul manath, serta penggunaan instrumen metodologi yang memiliki hubungan fiqh mengenai maqashid syariah sangat diperlukan karena penjelasan tersebut sesuai ilmu ushul fiqh tidak hanya sekedar terhadap pembahasan tentang sasaran syariah dengan pemeliharaan kegunaan dari kelima utama keperluan dasar yaitu akal, agama, harta dan jiwa. Penerapan dilakukan terhadap perekonomian keuangan serta bank syariah sesuai konsep tersebut. Maqashid al-syariah sendiri tidak menjadi faktor yang 
utama dalam menghasilkan peran berlipat sebagai penentu dan mewujudkan produk ekonomi syariah yaitu alat kontrol sosial dan penerapan sesio-ekonomi dalam menciptakan faedah dan kegunaan manusia, namun peran lebih dari maqashid syariah memberi aspek filosofi serta rasional pada aktivitas ijtihad perekonomian syariah kontemporer yang melahirkan produk hukum ekonomi islam (Tianto, 2015).

Pada dasarnya, tujuan maqashid Al-Syari'ah ialah memperoleh faedah. Sesuai sistem ekonomi masa kini banyak lembaga keuangan yang memegang prinsip syariah dan memiliki penerapan Maqashid Al-Syariah, antara lain:

\section{Penerapan Terhadap Perbankan Syariah}

Dengan tidak adanya Maqashid Al-Syariah, maka dapt terjadi kehilangan substansi syariah berdasarkan seluruh regulasi, perbankan, fatwa, keuangan, kebijakan (moneter dan fiscal), dan produk. Dengan tidak adanya Maqashid Al-Syariah tersebut dapat dipastikan pengembangan serta regulasi fiqh muamalah disesuaikan pada rumusan perbankan dan keuangan, yang menjadi diam dan tetap. Dampaknya ialah kelembagaan keuangan dan perbankan syariah menghasilkan kesulitan dan keterlambatan perkembangan.

Searah dengan peningkatan keuangan dan bank syariah yang semakin pesat memunculkan berbagai permasalahan yang tentunya diharuskan untuk diubah secara bertingkat. Maka, kewajiban dari pengawas perbankan syariah berdasarkan Bank Indonesia di banyak tempat harus mempunyai kemampuan ilmu syariah sesuai standarisasi diantaranya ilmu ushul fiqh dan Maqashid Al-Syari'ah yang hingga saat ini diabaikan oleh kelembagaan otoritas tersebut.

Berdasarkan pernyataan Abdul Wahab Khalaf, menerangkan bahwa mempelajaran dan mengetahui mengrnai al-maqashid al-syari'ah mampu menjadi alat bantu untuk mengerti suatu redaksi Alqur'an dan Sunnah, berperan dalam menuntaskan dalil yang berlawanan serta menjadi bagian utama dalam menentukan aturan hukum pada suatu kasus yang ketetapan hukum tidak dicantumkan pada Alqur'an dan Sunnah apabila memanfaatkan kajian kebahasaan. Ini menunjukkan bahwa maqashid al-syari'ah menjadi bagian penting dalam implementasi keuangan dan perekonomian terbaru yang todak sama dengan implementasi bank syariah di beberapa Negara (Nasuka \& Subaidi, 2017).

Penerapan teori yang dikemukakan al-syatibi pada perbankan syariah adalah sebagai berikut :

A. Perlindungan agama, yaitu diciptakan dengan penerapan Alqur'an, hadits, serta hukum Islam lain yang menjadi acuan dalam melakukan seluruh sistem kinerja dan produk. Hadirnya Dewan Syariah Nasional dan Dewan Pengawas Syariah menjadikan sahnya suatu perbankan sesuai prinsip dan nilai keislaman yang semakin terbukti dan juga menghasilkan kepercayaan dari umat muslim hingga non muslim.

B. Perlindungan kejiwaan, yaitu diciptakan dengan penerapan pada masing-masing transaksi di suatu bank syariah. Secara sosiologis dan psikologis, berbagai akad yang diterapkan dari pihak mengarahkan manusia sehingga memiliki kepercayaan yang diberikan dan menghargai satu sama lain. Selanjutnya, yaitu diwujudkan melalui pihak yang memiliki kepentingan baik pengguna dan perbankan dalam menemui pengguna yang ditekankan untuk memiliki sikap, pakaian, dan komunikasi dengan santun dan sesuai ajaran Islam dan diterapkan pada nasabah (Rizki, 2017).

C. Perlindungan akal, yaitu terhadap pengguna dan pihak perbankan yang diwujudkan karena diharuskan untuk senantiasa mengungkap seluruh rincian tentang sistem produk dari pihak perbankan dan tidak diperbolehkan untuk menutupi barang apapun. Disini 
dapat dilihat bahwasanya nasabah diarahkan untuk memahami bersama pada saat menjalankan transaksi di perbankan dengan tidak adanya perbuatan dzalim dari pihak perbankan, dimana bank tersebut juga berperan memberi pemahaman pada nasabah dengan memberi edukasi di tiap-tiap produk yang diberi pada nasabah.

D. Perlindungan harta, yaitu diwujudkan secara pasti pada masing-masing produk yang dibuat perbankan sebagai bentuk upaya dalam memelihara dan menempatkan dana pengguna dengan efektif serta halal dan juga dibolehkan dalam mengambil profit secara adil. Dan juga dilihat berdasarkan implementasi sistem zakat yang memiliki tujuan dalam membenahi harta nasabah dengan terbuka dam bersamaan.

E. Perlindungan turunan, yaitu diwujudkan degan menjaga 4 komponen diatas, maka jaminan dana nasabah dipastikan halal dan menghasilkan dampak untuk keluarga, kerabat, dan lainnya dalam memberi nafkah dari hasil dana tabungan tersebut (Zaki \& Bayu, 2015).

Selain itu pembahasan tentang Maqashid Al-Syari'ah secara spesifik juga dibahas pada akad/produk perbankan syariah diantaranya sebagai berikut:

A. Maqashid Al-Syari'ah Pada Investasi dengan Akad Mudharabah

Dalam hal ini ditinjau berdasarkan dua hal antara lain:

Apabila seseorang mempunyai nilai lebih terhadap harta dan mempunyai keterampilan dalam mengelola hartanya, maka diharuskan untuk melakukan serta mengelola secara pribadi. Dan apabila usaha sesuai sasaran (berhasil), maka semua nilai untung yang didapat menjadi haknya. Sejalan dengan maqashid alsyari'ah bahwasanya nilai untung dari harta sebagai hak pemilik, apabila tanpa bantuan serta hak orang lain dalam dana tersebut disesuaikan pada firman Allah berikut:

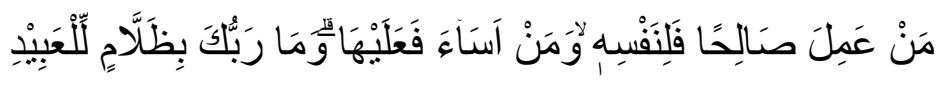

Artinya:

Barang siapa melakukan kebaikan maka pahala baginya dan barang siapa yang mengerjakan perbuatan buruk maka dosa baginya sebagai tanggungannya sendiri. Dan Tuhanmu tidak mendzalimi hamba-Nya sama sekali. (Fushilat [41]: 46)

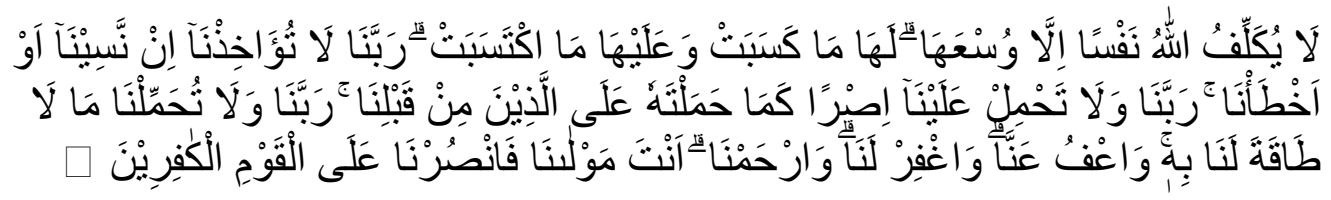

Artinya:

Allah tidak memberi beban pada seseorang kecuali disesuaikan pada kesanggupan yang dimilikinya. Dia memperoleh pahala melalui kebaikan yang dilakukan serta dia memperoleh siksaan dari keburukan yang dilakukannya. Mereka berdoa: Ya Tuhan kami, jangan Engkau beri hukuman pada kami apabila kami lupa ataupun berbuat kesalahan. Ya Tuhan kami, jangan Englah berikan beban pada kami seberat beban yang telah didapatkan sebelum kami. Ya Tuhan kami, jangan Engkau bebankan pada kami sesuatu yang tidak dapat kami pikul. Berilah maaf pada kami, ampunkan perbuatan kami, dan berilah rahmat untuk kami. Engkaulah 
yang melindungi kami, maka berilah pertolongan pada kami menghadapi orangorang kafir. (QS. Al-Baqarah [2]: 286)

Yang kedua, apabila seseorang mempunyai harta namun tidak dapat atau tidak mempunyai keahlian dalam mengelola 100 sendirian, maka ia dapat menyerahkan pada pihak lainnya dalam melakukan pengelolaan. Ini menjadi satu dari berbagai tujuan Maqashid Al-Syari'ah (Andiko, 2018).

B. Maqashid Al-Syari'ah pada Jaminan dalam Akad Mudharabah dan Musyarakah Pada prinsip pembiayaan mudharabah tanpa jaminan dimana sesuai definisi dari akad mudharanh dan musyarakah sesuai fatwa DSN MUI Nomor 08 Tahun 2000. Tetapi guna mudharib tidak melakukan kesalahan, maka LKS mampu mendapatkan jaminan melalui mudharib ataupun pihak ketiga. Jamin dapat diterima jika mudharib dibuktikan telah melakukan penyimpangan pada berbagai hal yang disetujui seluruh pihak. Maka dadi itu, sesuai prinsip pembiayaan musyarakah tanpa jaminan, akan tetapi dalam mencegah adanya kesalahan, maka LKS dapat mendaptkan jaminan.

Pada prinsip akad rahn bahwa diperbolehkan karena hutang yang muncul dikarenakan akad qardh, transaksi tanpa tunai, ataupun akad sewa menyewa atau ijarah yang biaya ujrahnya dibayar tanpa tunai; Pada prinsip akad amanah tidak dapat menjamin barang atau marhun, tetapi guna pemilik amanah tidak melakukan kesalahan perilaku atau moral hazard. Kelembagaan Keuangam Syariah dibolehkan mendapatkan jaminan barang karena ini dituangkan terhadap fatwa DSN Nomor 92 Tahun 2014 mengenai biaya yang diberikan dengan rahn atau AlTamwil Al-Mautsuq Bi Al-Rahn. Adapun ketetapan hukum disesuaikan pada maqashid sesuai syariat berbagai akad amanah yang dijelaskan di atas, diantaranya karena nilai untung yang ada dan muncul bersamaan dengan resiko atau alghunmu bi alghurmi. Apabila nilai untung tersebut terjamin, maka karakter pokok akad dapat dihilangkan dan tidak diubah seperti pinjaman yang berbunga (Andiko, 2018).

C. Maqashid Al-Syari'ah Pada Transaksi Multi Akad

Transaksi multi akad termasuk al-'uqud ghairu al-musamah yaitu akad-akad kontemporer yang tidak ada bahkan tidak dapat dijelaskan pada kitab-kitab turats. Multi akad sendiri dibuat untuk memenuhi kebutuhan pasar, memperbesar keuntungan, meminimalisir resiko, dan lainnya.

Multi akad sebenarnya boleh saja diterapkan asalkan tidak ada dalil yang melarang, maqashidnya pun harus jelas agar tidak ada pihak yang dirugikan atau terzalimi, agar multi akad menjadi sah maka harus memenuhi unsur yang sesuai syariat .

Dalam fiqh sendiri akad-akad pelengkap diberikan dispensasi berbeda dengan akan inti, artinya hal-hal yang harusnya dilarang pada akad tetapi diperbolehkan pada akad pelengkap hal ini sesuai urf dan keterangan para ahli yang mendapat pengesahan oleh dewan pengawas syariah atas dasar kaidah yaitu sesuai prinsip akad yang melengkapi diberikan tolerir berbagai hal yang dilarang dan tiadk dapat diberikan tolerir pada saat berdiri sendiri.

Berikut multi akad yang ada pada bank syariah:

a) Akad ijarah muntahiya bi al-tamlik (IMBT) yang terbagi atas akad ijarah, wa`d, dan akad tamlik atau bai atau hibah.

b) Akad musyarakah mutanaqishah yaitu kombinasi antara akad musyarakah atau syirkah `inan, wa`d untuk bai`, dan akad bai ataupun akad ijarah. 
c) Akad murabahah li al-amir bi al-syira' yaitu kombinasi wa`d, wakalah, dan jual beli.

d) Produk gadai emas yaitu kombinasi dari akad qardh, rahn, serta ijarah.

e) Tabungan haji yaitu kombinasi akad qardh serta rahn.

f) Istishna' parallel yaitu kombinasi akad istishna' serta wakalah.

g) Mudharabah muqayyadah yaitu kombinasi akad mudharabah serta akad sebagai objek mudharabah.

h) Produk multi level marketing yaitu kombinasi akad bai', ju`alah, serta samsarah.

Berdasarkan akad tersebut, ditekankan bahwa kewajiban serta hak berbagai pihak akad untuk memperoleh haknya dengan tidak adanya kedzaliman apapun. Berdasarkan nash Alqur'an dan Hadits menerangkan bahwa adanya beberapa akad antara lain transaksi, rhan, dan lainnya yang diterangkan rukun, syarat, serta ketetapan hukum akad tersebut. Akad yang dijelaskan tersebut termasuk pada nash serta kitab turats yang menjadi jual beli karena sesuai pada keinginan masyarakat. Akad yang disebutkan dalam nash dan kitab turats itu yang menjadi jual beli karena disesuaikan pada keinginan masyarakat pada saat itu. Apabila masyarakat sekarang memerlukan akad terbaru dalam mencukupi keperluan hajatnya, maka ini artinya diperbolehkan tetapi tidak menyimpang dari berbagi hal sesuai prinsipnya atau tsaqabit dalam permasalahan muamalah antara lain jelas yaitu wudhuh, adil, serta tanpa melakukan kesalahan dari ketetapan fiqh (Andiko, 2018).

D. Maqashid Al-Syari'ah Pada Rahn dan Pemanfaatan Marhun (Barang Gadai)

Berdasarkan fatwa DSN mengenai rahn diterangkan bahwasanya pinjaman dilakukan dengan menggadai suatu barang untuk jaminan piutang atau rahn yang diizinkan. Dan jaminan uang menggunakan suatu barang penting (berharga) seperti emas yang diizinkan sesuai nash Alqur'an, hadits, serta faedah. Sesuai dengan firman Allah SWT:

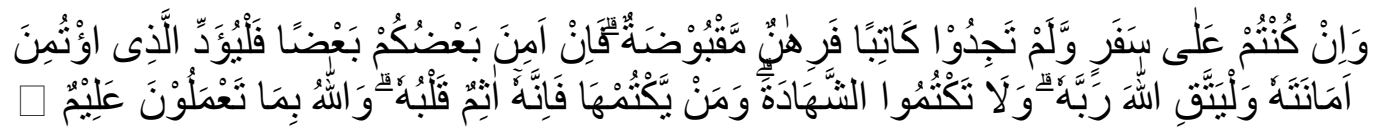

Artinya:

Dan jika dirimu dalam perjalanan sedang kamu tidak mendapat seorang penulis, maka diharuskan untukmu menjamin dengan suatu barang yang dipegang. Namun, jika beberapa darimu meyakini beberapa lainnya, diharuskan dirinya bertakwa pada Allah sebagai Tuhan-Nya, serta juga jangan dirimu menyembunyikan kesaksian, ini dikarenakan barang siapa yang melakukan itu, sungguh memiliki hati kotor dan berdosa. Allah Maha Mengatuhi seluruh yang dirimu lakukan (QS. Al-Baqarah [2]: 283)

Adapun mengenai barang gadai yang dimanfaatkan, sesuai fatwa DSN MUI Nomor 25 Tahun 2002 mengenai rahn diterangkan bahwa "Barang gadai yang disebut marhun dan pemanfaatannya tetap sebagai milik pihak penggadai atau rahun. Barang gadai tidak dapat digunakan bagi penerima gadai (murtahin) terkecuali diberi izin oleh penggadai, dan tanpa dikurangi nilai barang gadai, dan manfaatnya hanya untuk mengganti pembiayaan menjaga dan merawatnya. Penerima gadai memiliki hak dalam menjaga barang hingga seluruh piutang dilunaskan rahn dan diberlakukan dalam akad mu'awadhah yaitu jual beli 
dikarenakan rahn sebagai barang yang ditanggng dan diadakan apabila satu sama lainnya tidak saling meyakini. Tidak dapat dilakukan terhadap akad amanah yaitu mudharabah serta musyarakah terkecuali apabila syarat dipergunakan menjadi bukti tetap yang dikelola serta syarik pada syarat yang ditetapkan.

E. Maqashid Al-Syari'ah Pada Jual Beli Emas Secara Tidak Tunai

Para ulama berbeda pendapat mengenai hukum jual beli emas secara tidak tunai (angsuran). Menurut mayoritas fuqaha (mazhab Hanafi, Maliki, Syafi'i dan Hanbali) bahwa jual beli emas secara angsuran itu tidak boleh.Sedangkan menurut Ibnu Taimiyah, Ibnu Qayyim dan beberapa ulama kontemporer, jual beli emas secara angsuran itu hukumnya boleh.

Namun dari beberapa perselihan ini disimpulkan berdasarkan pendapat terkuat bahwa boleh jual beli emas dengan angsuran karena emas adalah barang, bukan harga (uang). Ini untuk memudahkan urusan masyarakat dan menghilangkan kesulitan, Fatwa DSN juga sangat memperhatikan maqshad (tujuan atau maksud) dari keharaman jual beli emas. Karena itu DSN membolehkan jual beli emas secara tidak tunai. Jual beli emas secara tidak tunai, baik melalui jual beli biasa atau jual beli murabahah itu hukumnya boleh (mubah/jaiz) selama emas tidak menjadi alat tukar yang resmi (uang) dengan ketentuan.

\section{KESIMPULAN}

Berdasarkan rumusan masalah pada penelitian ini maka dapat disimpulkan bahwa pererapan Maqashid al-syari'ah pada perbankan syariah sudah sesuai dengan memerhatikan indikator pada maqashid al-syari'ah yaitu agama (al-din), jiwa (alnafs), akal (al-'aql), harta (al-mal), dan keturunan (al-nasl). Begitu juga pada Investasi dengan Akad Mudharabah, pada Jaminan dalam Akad Mudharabah dan Musyarakah, Pada Transaksi Multi Akad, Pada Rahn dan Pemanfaatan Marhun (Barang Gadai), Pada Jual Beli Emas Secara Tidak Tunai.

\section{UCAPAN TERIMA KASIH}

Ucapan terimakasi saya berikan kepada dosen pembimbing saya di matakuliah ushul fiqh keuangan yaitu ibu Dr. Nurhayati, MA yang telah memberikan semangat dan dorongan kepada saya untuk bisa membuat penelitian ini

\section{DAFTAR PUSTAKA}

Andiko, Toha (2018) ,Maqashid Al-Syari'ah Dalam Ekonomi Islam, Yogyakarta: Penerbit Samudera Biru.

Ibrahim,Azharsyah .dkk,( 2021),Pengantar Ekonomi islam ,Jakarta: Departemen Ekonomi dan Keuangan Syariah - Bank Indonesia,

Ibrahim,Duski, (2019),Al-qawaid almaqashidiyah:kaidah-kaidah maqashid,Yogyakarta:Ar-ruzz media.

Ika dan Abdul, (2014), Prinsip Dasar Ekonomi Islam Perspektif Maqashid Al-Syari'ah Jakarta:Kencana.

Mawardi,Ahmad Imam i, (2010),Fiqh Minoritas: Fiqh Al-Aqalliyyât dan Evolusi Maqâshid al-Syarî'ah dari Konsep ke Pendekatan, Yogyakarta:Lkis Printing Cemerlang.

Moh Nasuka dan Subaidi, (2017) “MAQĀṣID SYARĪ'AH Sebagai Koridor Pengelolaan Perbankan Syariah", Iqtishoduna Vol. 6 No. 2 
Muhammad Zaki dan Bayu, (2015)," Aplikasi Maqashid asy Syariah Pada Sistem

Keuangan Syariah", Jurnal Bisnis dan Manajemen Islam Vol. 3, No. 2,

Nurhayati \& Ali Imran Sinaga, (2019),Fiqh dan Ushul Fiqh ,Jakarta: Kencana.

Rizki ,Sandi , (2017) “Aplikasi Maqashid Al-Syari'ah Dalam Bidang Perbankan

Syariah", Jurnal Ekonomi dan Keuangan Syariah Vol. 1 No.2

Sarwat,Ahmad, 2019,Maqashid Al-Syari'ah ,Jakarta:Rumah Fiqih Publishing

Sodiqin,Ali, 2012,Fiqh dan Ushul Fiqh ,Yogyakarta:Beranda Publishing

AgusTianto (2015), "Maqashid Syariah dalam Ekonomi, Keuangan danPerbankan Syariah", dalam

https://www.iqtishadconsulting.com/content/read/blog/artikel/maqashidsyariah-dalam-ekonomi-keuangan-dan-perbankan-syariah , dikutip pada 11 oktober 2021 